This article was downloaded by: [b-on: Biblioteca do conhecimento online ISPA]

On: 28 J anuary 2012, At: 04: 42

Publisher: Routledge

Informa Ltd Registered in England and Wales Registered Number: 1072954

Registered office: Mortimer House, 37-41 Mortimer Street, London W1T 3J H, UK

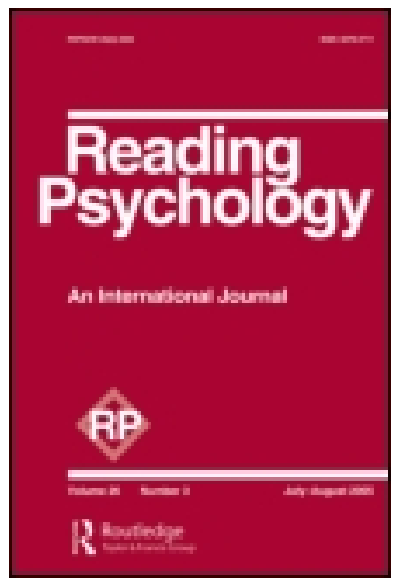

\title{
Reading Psychology
}

Publication details, including instructions for authors and subscription information:

http:// www. tandfonline.com/loi/ urpy20

\section{Motivation for Reading and Writing in Kindergarten Children}

\author{
Lourdes Mata $^{\text {a }}$ \\ ${ }^{a}$ Instituto Superior de Psicologia Aplicada, Lisbon, \\ Portugal
}

Available online: 12 May 2011

To cite this article: Lourdes Mata (2011): Motivation for Reading and Writing in Kindergarten Children, Reading Psychology, 32:3, 272-299

To link to this article: http:// dx.doi. org/ 10.1080/ 02702711.2010.545268

\section{PLEASE SCROLL DOWN FOR ARTICLE}

Full terms and conditions of use: http://www.tandfonline.com/page/termsand-conditions

This article may be used for research, teaching, and private study purposes. Any substantial or systematic reproduction, redistribution, reselling, loan, sub-licensing, systematic supply, or distribution in any form to anyone is expressly forbidden.

The publisher does not give any warranty express or implied or make any representation that the contents will be complete or accurate or up to date. The accuracy of any instructions, formulae, and drug doses should be independently verified with primary sources. The publisher shall not be liable for any loss, actions, claims, proceedings, demand, or costs or damages 
whatsoever or howsoever caused arising directly or indirectly in connection with or arising out of the use of this material. 


\title{
MOTIVATION FOR READING AND WRITING IN KINDERGARTEN CHILDREN
}

\author{
LOURDES MATA \\ Instituto Superior de Psicologia Aplicada, Lisbon, Portugal
}

\begin{abstract}
This study characterizes the reading and writing motivations of kindergarten children. Four hundred fifty-one children participated in the study, answering questions measuring value, self-concept, and enjoyment of reading and writing. A factor analysis validated the conceptual motivational constructs. Findings indicate that kindergarten children have high motivation for both reading and writing, although scores for writing motivation were not as high as those for reading. Among the group studied, boys' and girls' motivational profiles are not markedly differentiated. Implications for future research and educational practices are discussed.
\end{abstract}

The main purpose of this study is to characterize the literacy motivations of kindergarten children taking into consideration not only their reading and writing motivational profiles but also gender differences. To fulfill this aim we also constructed a reliable measurement for literacy motivation.

Investigation in the field of emergent literacy has highlighted that literacy knowledge emerges at a very early stage, through children's contacts and experiences with writing and reading, in everyday life, even before they attend school (Alves Martins, 1994; Clay, 1999, 2000; Ferreiro, 1988; Goodman, 1989, 1996; Sulzby, 1989). However, despite the wide range of investigation concerning emergent literacy, the affective components of this process-attitudes and motivation for reading and writing-are not well characterized in preschool-age children. The existing work concerning the affective components of the literacy apprenticeship process is mainly focused on children who are already attending primary school or are even older (Baker \& Wigfield, 1999; Gambrell, Palmer, Codling, \& Mazzoni, 1996; McKenna,

Lourdes Mata is an FCT (Science and Technology Foundation) grant holder, PRAXIS XXI Programme.

Address correspondence to Lourdes Mata, Instituto Superior de Psicologia Aplicada, Rua Jardim do Tabaco, 34, 1149-041, Lisbon, Portugal. E-mail: lmata@iapa.pt 
2001; McKenna, Kear, \& Ellsworth, 1995; Monteiro \& Mata, 2001; Nolen, 2007; Wilson \& Trainin, 2007). Nevertheless, children interact with written language from very early on and develop early concepts concerning its functions and conventions. Thus, it is natural that they should also develop feelings and attitudes towards literacy-related activities and that, parallel to this, motivation for literacy should begin to develop. The study of these affective components among young children is therefore essential, because children's motivation and attitudes play an essential role in their literacy learning and engagement (Guthrie \& Anderson, 1999; Wigfield, 1997).

\section{Literacy Engagement}

Verhoven and Snow (2001) maintained that to ensure reading engagement and fluency presupposes the existence of a number of factors, such as understanding the uses, functions, and value of literacy-something that very often results from children's contacts with the literacy practices of the adults with whom they are involved; the enthusiasm for learning to read, which usually results from positive experiences with literacy during the preschool years; children's expectations of success when they learn to read; and the existence of environments that facilitate and are suited to the acquisitions that children gradually make. In other words, it implies an early global involvement with literacy. To promote literacy engagement, it is important to consider literacy development "within the larger context of the child's 'developmental niche" (Baker, Afflerbach, \& Reinking, 1996, p. xix). Differential experiences during the preschool years may have repercussions on reading engagement in school years. Parental literacy practices and all literacy experiences and activities developed in kindergarten contexts may contribute to literacy engagement (Baker, 1999; Mata \& Pacheco, 2009; Morrow, 1997; Sonnenschein \& Munsterman, 2002). Moreover, reading instruction strategies and goals for instructional intervention have an impact on motivational processes and reading engagement (Guthrie et al., 2009; Guthrie, McRae, \& Klauda, 2007; Wigfield, Guthrie, Tonks, \& Perencevich, 2004).

Baker, Drehen, and Guthrie (2000) stated that the study of engagement must seek to understand the cognitive, motivational, and social dimensions of writing and reading instruction. 
Accordingly, engaged readers "read frequently for interest, enjoyment and learning" (p. 9). Engaged readers are therefore seen as motivated, strategic, knowledgeable and socially interactive (Baker et al., 1996). The engaged reader is someone who is motivated to read for a variety of purposes, actively participates in multiple literacy-related activities, and socially interacts through his or her literacy (Baker \& Wigfield, 1999).

\section{Literacy Motivation}

Literacy motivation is usually considered as multifaceted and complex. Authors in this field argue that motivation cannot be reduced to a single factor that people have or do not have (Guthrie \& Wigfield, 1997; Wigfield, 2000). The conceptual framework of literacy motivation has its foundations in prominent motivation constructs of current motivation theories. Some of these constructs are related to the individual's beliefs, values, and goals for achievement; others concern intrinsic and extrinsic motivation and social motivation, which are central elements to understanding literacy motivation (Guthrie \& Wigfield; Wigfield). Therefore, literacy motivation must be understood in terms of goals or reasons for reading or writing. These reasons may be associated with different aspects such as task value, expectancies, self-efficacy, or goal orientation (Eccles \& Wigfield, 2002; Guthrie et al., 2007; Mazzoni, Gambrell, \& Korkeamaki, 1999), and people may differ in their reasons, goals, and expectancies and consequently be motivated in a variety of ways. This multifaceted structure is evident when authors in the field of literacy consider reading and writing motivation as multidimensional constructs (Baker \& Wigfield, 1999; Guthrie et al., 2009; Pajares \& Valiante, 2001; Pitcher et al., 2007; Schutte \& Malouff, 2007) and organize instruments to characterize reading and writing motivation with several dimensions, allowing a multifaceted view of these constructs (Codling \& Gambrell, 1997; Garcia \& Caso, 2004; Pajares \& Valiante; Scher \& Baker, 1997; Wigfield, Guthrie, \& McGough, 1996).

\section{Characteristics of Literacy Motivation}

According to Wigfield (2000), most children come to school curious about learning and with a high expectation of success. 
Despite this, the belief that children have in their own competence tends to decline as they advance in school (Eccles, O'Neill, \& Wigfield, 2005), and intrinsic motivation often declines as well (Harter, Whitesell, \& Kowalksi, 1992; Lepper, Corpus, \& Iyengar, 2005).

Research into literacy motivation also reflects these features of decline. As children get older, it seems that, at least in some aspects, their motivations for reading and writing decrease (Baker \& Wigfield, 1999; Gambrell et al., 1996; Monteiro \& Mata, 2001; Pajares \& Cheong, 2003; Pajares, Valiante, \& Cheong, 2007; Wigfield \& Guthrie, 1997).

Wigfield and Guthrie (1997), when comparing fourth- and fifth-grade children, identified differences in several reading motivational dimensions (efficacy, recognition, and social reasons), with fourth-grade students having higher scores than those in the fifth grade. Similar results were presented by Baker and Wigfield (1999) when comparing fifth- and sixth-grade students for social reasons and recognition dimensions. Even using a different questionnaire to assess reading motivation, Gambrell et al. (1996) also found differences between third and fifth graders, with younger students having higher mean scores in the value of reading dimension.

Monteiro and Mata (2001) studied the motivation profiles for reading in Portuguese students from the first to the fourth grade. Again, a significant motivational decline was found, taking into account enjoyment and recognition. However, for self-concept as a reader, scores were higher for older students. This rise of selfconcept scores can be explained by the children's age and their characteristics as readers. Children participating in this research were at the beginning of compulsory school, and students in first grade did not yet know how to read and were just at the beginning of the learning process, whereas most of the third and fourth graders were already fluent readers. Consequently, their judgments as readers (self-concept as a reader) reflected the effective differences in their reading performance (Monteiro \& Mata, 2001).

In recent research with 1,405 students of the three cycles of compulsory school in Portugal, from third to ninth grades, Mata, Monteiro, and Peixoto (2009) also identified a reliable effect of grade level in students' motivation for reading profiles. 
Significant differences were found in several dimensions (enjoyment, importance, social recognition, social reasons, competence, self-perception), and all scores decreased with grade level.

Meece and Miller (1999), using an achievement goal framework to examine changes in third- to fifth-grade students' motivation for reading and writing, experienced similar results. Data showed significant declines in task mastery and performance goals within school year and across grade levels both for reading and writing. Within a developmental perspective, Pajares and Cheong (2003) analyzed achievement goal orientations in writing with 9- to 17-year-old students. Results showed that the strength of task goals orientation decreased from elementary school to middle school and then increased in high school. Performance approach goals also decreased from elementary school to middle school and stabilized.

Several other researchers reported similar results, showing that writing self-efficacy beliefs diminished as students move from elementary school to middle school and remained at that level during high school (Pajares \& Cheong, 2003; Pajares et al., 2007) and that students in the beginning of middle school had stronger confidence in their writing skills than do students in Grades 7 and 8 (Pajares \& Valiante, 1999).

All motivation research previously presented was conducted with children who were already attending school, and they reported a decline in motivation, sometimes varying in the strength and in the amount of motivation dimensions affected. These differences may be due to different factors such as the age of students participating, the instruments used, and the teaching practices in the classroom. Wigfield (2000) considered that differences in students' ages are associated with a different capacity to understand their own performance. Moreover, teaching practices may contribute to a decline in some children's motivation. Recent research suggests the possibility that different instructional approaches toward literacy are likely to have diverse effects on students' acquisition of conceptual knowledge and strategic development as well as on their reading motivation (Guthrie et al., 2004).

The lack of research concerning reading and writing motivation of kindergarten children makes it impossible for us to characterize it. However, there is some research with preschool and 
kindergarten children that looks at reading and writing attitudes (Saracho \& Dayton, 1991; Sperling \& Head, 2002), whose conclusions can contribute to a better understanding of the affective component of the reading and writing acquisition process.

Researchers consider that attitudes toward reading, realized as the individual's feelings toward reading, should relate to the individual's motivation because they influence how much individuals involve themselves in reading (Wigfield, 1997). However, attitudes conceived as the sense of liking are distinct from motivation because "attitudes are not objectives that guide behavior and are fulfilled. Attitudes do not reflect a belief that prompts behavior as motivations do. Attitudes are affective responses that accompany a behavior of reading initiated by a motivational state" (Guthrie \& Knowles, 2001, p. 161). Attitudes can therefore be linked directly to motivation and provide key information to a better understanding of the motivational process.

In a study of reading attitudes in young children, Saracho and Dayton (1991) identified a multidimensional structure (general reading, library reading, listening reading, oral reading) among 3-, 4-, and 5-year-old children, although with some structural differences between age groups. Results suggested significant attitudinal differences between 3-year-old children as opposed to 4-and 5 -year-old children, with an increase in positive reading attitudes as children get older. Despite their age, children's attitudes scores were consonant with teachers' evaluations about children's attitudes toward reading activities.

Sperling and Head (2002) also developed research with prekindergarten and kindergarten children, measuring attitudes for school reading activities, nonschool reading activities, and library reading activities. Findings indicated a slight decrease in reading attitudes during the kindergarten year; however, average values were high, indicating positive attitudes toward reading.

\section{Gender Differences in Literacy Motivation}

Another variable affecting motivation profiles that has been focused on is gender and, once again, we find a degree of similitude between the results of various studies that have been conducted on this theme. In practically every dimension in which gender differences have been found, it is girls who display higher motivational scores. Baker and Wigfield (1999) have identified a 
gender effect in fifth- and sixth-grade students for nine different reading motivation dimensions, with girls achieving higher motivational scores than boys. A similar effect was found in another research focusing on fourth- and fifth-grade students (Wigfield \& Guthrie, 1997), with girls exhibiting higher motivation concerning reading efficacy, importance of reading, and social reasons for reading and boys only being more motivated by competition in reading. These gender motivation characteristics have also been highlighted by Monteiro and Mata (2001) and again only boys presented higher motivational scores than girls in competition in reading. Even considering younger students Mazzoni et al. (1999) also found that girls' reading motivation scores were significantly higher than boys in the first and second grades.

An analogous gender effect is also prevalent in reading attitudes. McKenna (2001) analyzed a set of results concerning reading attitudes and concluded that the findings are consistent if we take into consideration that girls tend to possess more positive attitudes than boys. According to the author, gender-specific beliefs concerning what others expect from reading was one possible explanation for this gender difference. McKenna believed that it is not yet clear how these cultural expectations function, but research in different cultural settings shows that such expectations are not specific to a single culture.

Investigation concerned with writing also refers to some gender effects. Pajares and Valiante (1997) were unable to find differences in performance between fifth-grade boys and girls; however, girls reported higher self-efficacy, perceived writing as more useful, and had lower apprehension concerning writing. Therefore, the girls expressed greater confidence in themselves as writers. Meece and Miller (1999) identified gender differences among students in Grades 3 to 5 when analyzing their writing achievement goals; boys reported stronger work avoidance goals than girls.

Similar characteristics were reported in a research with elementary school students in Grades 3, 4, and 5, with girls having stronger writing self-concept as well as lower apprehension (Pajares, Miller, \& Johnson, 1999).

\section{Aims}

The main purpose of this study is to characterize literacy motivations of kindergarten children considering not only their 
reading and writing motivation profiles but also to analyze gender differences. Thus, the primary aim of this article is to assess not only the motivations for reading but also those for writing in children attending kindergarten. There has been previous research about these topics with students attending compulsory school (e.g., Gambrell et al., 1996; Meece \& Miller, 1999; Monteiro \& Mata, 2001; Pajares \& Cheong, 2003; Wigfield \& Guthrie, 1997), but reading and writing motivation in the preschool age group is not well characterized and their main features are unknown.

Findings of previous studies with preschool and firstgrade students showed that they can make domain-specific selfjudgments and can differentiate their self-efficacy levels for different domains (e.g., reading, writing, spelling, math; Valeski \& Stipek, 2001; Wilson \& Trainin, 2007). Therefore, we intend to verify whether reading and writing motivations are also differentiated in kindergarten age children.

Considering that with older children gender differences have been reported in various motivational features (e.g., Baker \& Wigfield, 1999; Monteiro \& Mata, 2001; Pajares \& Valiante, 1997; Wigfield \& Guthrie, 1997) and also in attitudes toward reading (McKenna, 2001), we intend to identify the characteristics of these children's motivation profiles and analyze whether the variable gender effect is already evident in such early phases of reading and writing acquisition and development. To fulfill these aims we intend to construct a reliable measurement of literacy motivation.

\section{Method}

\section{Participants}

Research was undertaken in 32 kindergartens in the Lisbon area. The parents of all of the children participating were contacted and written permission was sought from them to participate in the study. Permission was granted by 451 parents and these comprised the core of the research sample. All children were in the final year of kindergarten and were expected to pass into the first grade at the beginning of the next school year. Their ages ranged from 
5 years 4 months to 6 years 5 months, with an average of 5 years 10 months. Boys accounted for $50.7 \%$ and $49.3 \%$ were girls.

The children were from different sociocultural backgrounds. The great majority of parents were evenly split between those who had completed higher education $(44.8 \%)$ and those whose academic paths ended somewhere between the 9th and 12th grades $(43 \%)$. Even so, a significant number of parents had not completed compulsory schooling $(12.2 \%)$.

\section{Instrument}

To set our scale-the Motivation for Reading and Writing Profile (MRWP)—we used Scher and Baker's (1997) Motivation for Reading Scale (MRS) for first- and second-grade children as a reference. This is a 16-item scale designed to assess four theoretically derived components of reading motivation: enjoyment, value, selfconcept, and library-related activities. We used 10 items from the MRS (Scher \& Baker) and we formulated another 26 items in order to compile a list of 36 items, half of which concerned reading situations and the other half writing situations (Appendix). Similar to the procedures found in MRS (Scher \& Baker, 1997), each item was composed of two contradictory statements, attributed to two different stuffed animal toys, and children were asked which animal they were more similar to and then whether they were "a little" or a "lot" like that stuffed animal. They were given two practice items before beginning the actual questionnaire.

Both of the reading-related items and those for writing covered three distinct aspects of motivation: Enjoyment of reading/ writing; value/importance of reading/writing; self-concept as a reader/writer.

\section{ENJOYMENT}

These items were designed to assess the degree of pleasure/ enjoyment that the child felt he or she could obtain from reading or writing situations (e.g., "This one thinks that reading is fun BUT This one thinks that reading is boring").

\section{VALUE/IMPORTANCE}

The purpose of these items was to assess the value that the children attributed to reading or writing (e.g., "This one thinks 
it's important to know how to write BUT This one doesn't think it's important to know how to write").

\section{SELF-CONCEPT AS A READER/WRITER}

The idea behind these items was to assess the child's selfconcept as a reader or writer (e.g., "This one thinks he's going to manage to write his schoolwork well BUT This one thinks that he's not going to manage to write his schoolwork well").

Each item was graded on a scale of 1 to 4 . The choice of a more positive affirmation could be scored as either 3 or 4, depending on the degree of identification, and the choice of a less positive affirmation could be scored as 1 or 2, again depending on the extent of the subject's identification (a little or a lot like that stuffed animal). If we calculate the average for all the items included in each dimension, we obtain three different scores on the basis of which it is possible to determine both individual and collective profiles of motivation for reading and writing.

\section{Procedures}

Children's participation was solicited by a letter sent to parents. The researcher's letter was distributed to them via kindergarten by kindergarten teachers and included information about the study aims and the importance of their children's participation.

All children for whom parents' permission was granted were interviewed. Interviews took about 15 minutes each and were conducted by the author and a trained research assistant, using two stuffed animals. Responses were recorded by the interviewer on a 4-point scale as described previously.

The instrument was administered aloud and individually during the last 3 months of the school year in a quiet room, away from the classroom.

\section{Results}

\section{Psychometric Properties of the Instrument}

To analyze psychometric properties of the MRWP we carried out an initial factor analysis, with the extraction method of principal component with a Varimax rotation. 
The matrix that resulted from this initial analysis contained nine factors and served to eliminate some items that appeared to be either isolated or integrated into a different factor from the one in which they were theoretically conceptualized. With the remaining 24 items, we then carried out one more factor analysis (Table 1). This analysis suggested three components. The rotated component matrix converges into a three-factor solution that is coherent with the theoretical framework.

A principal component analysis of factor scores for the three factors accounted for $51 \%$ of the variance. These three factors had eight items loading each at 0.48 or above and the mean loading score was 0.64 .

- Factor 1-Self-concept as a reader/writer-Eight items loaded at 0.65 or greater on the first factor. These items are concerned with how well children think they will read or write in the next year they attend school. This subscale includes statements about global perceptions as readers and writers and about how well children will do in specific tasks (e.g., schoolwork, stories). Four items recorded reading self-concept and four other items recorded writing self-concepts.

- Factor 2-Enjoyment of reading and writing-Eight items loaded at 0.45 or greater on the second factor. These items are related with the pleasure associated in literacy situations. Four items recorded reading enjoyment and other four items recorded writing enjoyment.

- Factor 3-Value of reading and writing-Eight items loaded at 0.56 or greater on the third factor. These items were based on reading and writing importance and on how useful the reader found the material in dealing with everyday situations. Items considered reading and writing situations equally.

The items loaded on each of the three factors created three subscales. As a result, the high scores on all subscales would indicate grater motivation to read.

In order to analyze the consistency of internal reliability of the subscales that resulted from this factor analysis, we calculated the Cronbach's alpha as follows: 0.82 (value of reading and writing), 0.87 (enjoyment of reading and writing), and 0.87 (selfconcept as reader and writer). 
TABLE 1 Factor Analysis and Factor Loadings of the Motivation for Reading and Writing Profile

\begin{tabular}{|c|c|c|c|}
\hline \multirow[b]{2}{*}{ Items } & \multicolumn{3}{|c|}{ Factors } \\
\hline & 1 & 2 & 3 \\
\hline $\begin{array}{l}\text { SCR 3-Is going to be able to read many } \\
\text { things next year }\end{array}$ & 0.661 & & \\
\hline SCR 9-Is going to learn to read well & 0.664 & & \\
\hline $\begin{array}{l}\text { SCR 12-Is going to manage to read } \\
\text { schoolwork well next year }\end{array}$ & 0.649 & & \\
\hline $\begin{array}{l}\text { SCR 15-Is going to be able to read stories } \\
\text { well next year }\end{array}$ & 0.711 & & \\
\hline $\begin{array}{l}\text { SCW21-Is going to be able to write a lot of } \\
\text { things next year }\end{array}$ & 0.651 & & \\
\hline SCW27-Is going to learn to write well & 0.680 & & \\
\hline $\begin{array}{l}\text { SCW30-Is going to manage to write } \\
\text { schoolwork well next year }\end{array}$ & 0.680 & & \\
\hline $\begin{array}{l}\text { SCW33-Is going to be able to write stories } \\
\text { well next year }\end{array}$ & 0.664 & & \\
\hline ER7-Enjoys looking at books & & 0.447 & \\
\hline ER10-Reading is a good way to spend time & & 0.552 & \\
\hline ER13-Reading is boring/fun & & 0.723 & \\
\hline ER16-Reading is good & & 0.639 & \\
\hline EW25—Enjoys writing & & 0.627 & \\
\hline EW28-Writing is a good way to spend time & & 0.686 & \\
\hline EW31-Writing is boring/fun & & 0.778 & \\
\hline EW34-Writing is good & & 0.751 & \\
\hline $\begin{array}{l}\text { VR2-It is necessary to know how to read for } \\
\text { everything to go well at school }\end{array}$ & & & 0.600 \\
\hline VR5-It is important to know how to read & & & 0.633 \\
\hline VR8-People learn things when they read & & & 0.673 \\
\hline $\begin{array}{l}\text { VR11-People can discover new things when } \\
\text { they read }\end{array}$ & & & 0.651 \\
\hline $\begin{array}{l}\text { VW20-It is necessary to know how to write } \\
\text { for everything to go well at school }\end{array}$ & & & 0.544 \\
\hline VW23-It is important to know how to write & & & 0.573 \\
\hline VW26-People learn things when they write & & & 0.620 \\
\hline $\begin{array}{l}\text { VW29-People can discover new things when } \\
\text { they write }\end{array}$ & & & 0.555 \\
\hline $\begin{array}{l}\text { Variance }(\%) \\
\text { Total variance: } 51 \%\end{array}$ & 18.3 & 17.4 & 15.3 \\
\hline
\end{tabular}

Note. Factor loadings less than 0.40 are not presented. $\mathrm{VR}=$ value of reading; $\mathrm{VW}=$ value of writing; ER = Enjoyment in reading; EW = Enjoyment in writing; $\mathrm{SCR}=$ self-concept as a reader; $\mathrm{SCW}=$ self-concept as a writer. 
All of the subscales possess relatively good internal consistency, given that they are all greater than 0.80 . Considering factor analysis results and the Cronbach's alpha scores we can conclude that the organization of the scale into three distinct dimensions is both reliable and valid according to acceptable indices of reliability and validity.

Separate psychometric analyses of the reading and writing items enabled us to see that both the factorial structure and the internal consistency were similar to the complete scale. Results presented in Tables 2 and 3 suggest that items concerning reading and those concerning writing can be used separately.

Factorial structures are clear, with three factors both for reading and for writing scales and with acceptable internal consistency scores, varying between 0.67 and 0.84 . These three factors

TABLE 2 Factor Analysis for the Motivation to Read Items

\begin{tabular}{|c|c|c|c|}
\hline \multirow[b]{2}{*}{ Items } & \multicolumn{3}{|c|}{ Factors } \\
\hline & 1 & 2 & 3 \\
\hline $\begin{array}{l}\text { SCR3-Is going to be able to read many } \\
\text { things next year }\end{array}$ & 0.669 & & \\
\hline SCR9-Is going to learn to read well & 0.717 & & \\
\hline $\begin{array}{l}\text { SCR 12-Is going to manage to read } \\
\text { schoolwork well next year }\end{array}$ & 0.722 & & \\
\hline $\begin{array}{l}\text { SCR 15-Is going to be able to read stories } \\
\text { well next year }\end{array}$ & 0.748 & & \\
\hline ER7-Enjoys looking at books & & 0.616 & \\
\hline ER10-Reading is a good way to spend time & & 0.675 & \\
\hline ER13-Reading is boring/fun & & 0.783 & \\
\hline ER16-Reading is good & & 0.697 & \\
\hline $\begin{array}{l}\text { VR2-It is necessary to know how to read for } \\
\text { everything to go well at school }\end{array}$ & & & 0.637 \\
\hline VR5-It is important to know how to read & & & 0.698 \\
\hline VR8-People learn things when they read & & & 0.708 \\
\hline $\begin{array}{l}\text { VR11-People can discover new things when } \\
\text { they read }\end{array}$ & & & 0.623 \\
\hline Variance $(\%)$ & 20 & 18.8 & 16.9 \\
\hline \multicolumn{4}{|l|}{ Total variance: $55.7 \%$} \\
\hline Cronbach's alpha & 0.75 & 0.74 & 0.67 \\
\hline
\end{tabular}

Note $. \mathrm{VR}=$ value of reading; $\mathrm{ER}=$ Enjoyment in reading; $\mathrm{SCR}=$ self-concept as a reader. 
TABLE 3 Factor Analysis for the Writing Motivation Items

\begin{tabular}{|c|c|c|c|}
\hline \multirow[b]{2}{*}{ Items } & \multicolumn{3}{|c|}{ Factors } \\
\hline & 1 & 2 & 3 \\
\hline EW25-Enjoys writing & 0.706 & & \\
\hline EW28-Writing is a good way to spend time & 0.700 & & \\
\hline EW31-Writing is boring/fun & 0.827 & & \\
\hline EW34-Writing is good & 0.809 & & \\
\hline $\begin{array}{l}\text { SCW21-Is going to be able to write a lot of } \\
\text { things next year }\end{array}$ & & 0.640 & \\
\hline SCW27-Is going to learn to write well & & 0.744 & \\
\hline $\begin{array}{l}\text { SCW30-Is going to manage to write } \\
\text { schoolwork well next year }\end{array}$ & & 0.776 & \\
\hline $\begin{array}{l}\text { SCW33-Is going to be able to write stories } \\
\text { well next year }\end{array}$ & & 0.750 & \\
\hline $\begin{array}{l}\text { VW20-It is necessary to know how to write } \\
\text { for everything to go well at school }\end{array}$ & & & 0.664 \\
\hline VW23-It is important to know how to write & & & 0.776 \\
\hline VW26-People learn things when they write & & & 0.628 \\
\hline $\begin{array}{l}\text { VW29-People can discover new things when } \\
\text { they write }\end{array}$ & & & 0.584 \\
\hline Variance $(\%)$ & 22.4 & 21.3 & 17.9 \\
\hline Total variance: $61.6 \%$ & & & \\
\hline Cronbach's alpha & 0.84 & 0.80 & 0.69 \\
\hline
\end{tabular}

Note. $\mathrm{VW}=$ value of writing; $\mathrm{PW}=$ Enjoyment in writing; $\mathrm{SCW}=$ self-concept as a writer.

for reading accounted for $55.7 \%$ of the variance and for reading $61.6 \%$.

It is therefore possible to outline one motivational profile for reading and another for writing.

\section{Motivational Profiles}

Using the MRWP and calculating the average value of the items on each subscale, we were able to characterize the motivational profiles of the children in our sample group.

The graph in Figure 1 represents this profile and sets out the values for each dimension: value of reading and writing; enjoyment of reading and writing; and self-concept as a reader/writer.

One characteristic that is evident is that the scores for each of the dimensions are quite high-over 3.5 on a scale of 1 to 4 . 


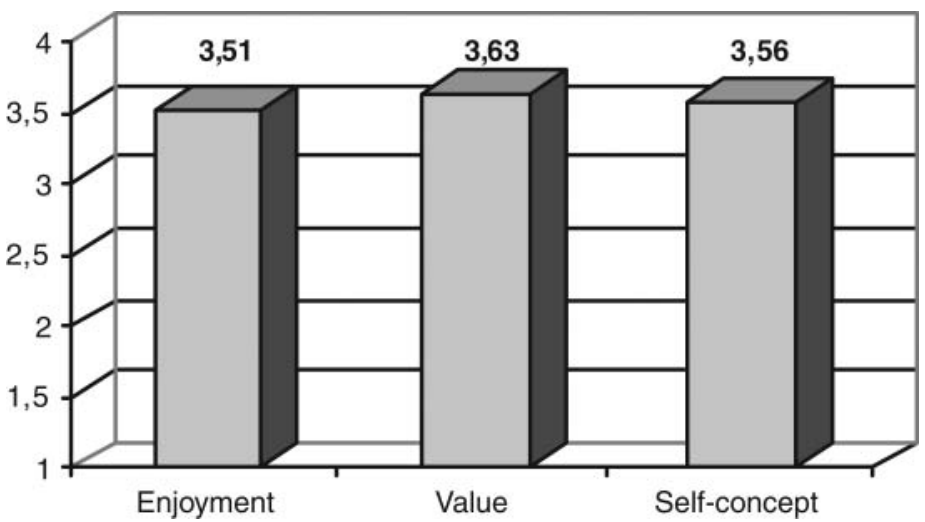

FIGURE 1 Children's motivational profile.

The dimension with the highest score was value $(M=3.63)$, followed by self-concept $(M=3.56)$, and finally enjoyment $(M=$ 3.51). These scores show that the children were highly motivated to read and write. However, although the scores were all high, there were some statistically significant differences between them: self-concept/enjoyment, $t(450)=2.298, p=.02$; self-concept/value, $t(450)=-3.661, p<.001$; enjoyment/value, $t(450)=-5.836, p<.001$. Therefore, the value of reading and writing is what motivates these children more, and Enjoyment is a less important reason for reading and writing.

\section{Reading and Writing Motivation Profiles}

As we have seen above, it is possible to outline separate profiles for reading and writing. The graph in Figure 2 compares these motivational profiles.

An initial analysis of these data enables us to note that the scores for both reading and writing were quite high for all the three dimensions. There was also similarity between the profiles for motivation for reading and writing for all three. In both profiles, value is the aspect that scores highest, followed by selfconcept and finally enjoyment. It would thus seem that these kindergarten-age children attribute high levels of value or importance to reading and writing more easily than they associate them with situations that give them pleasure. 


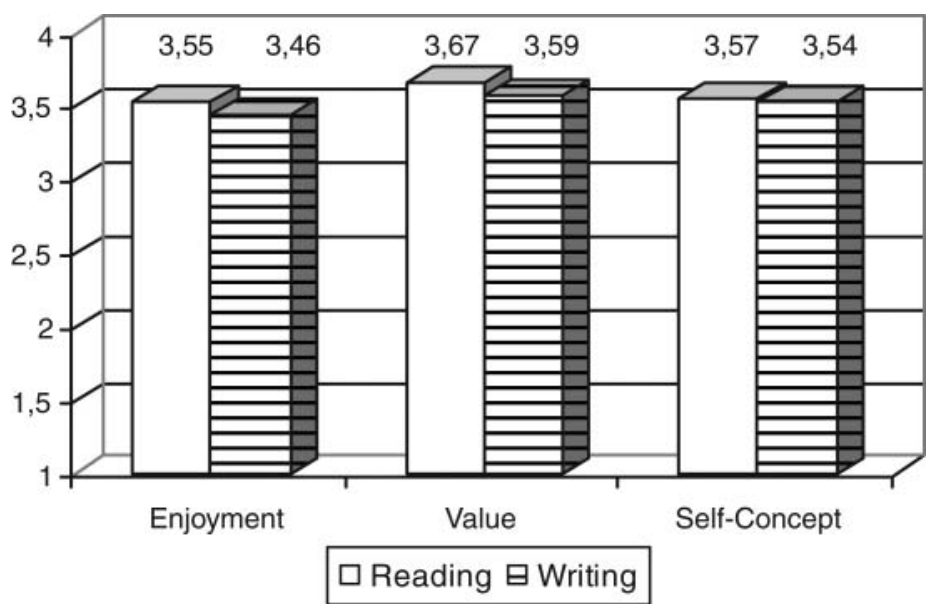

FIGURE 2 Comparison between the motivational profiles for reading and writing.

However, despite the parallels, there are some differences between the reading and writing motivation profiles. A dimensionby-dimension comparative analysis showed that the scores for reading were always higher than those for writing and that these differences were statistically significant for both value, $t(450)=$ $5.175, p<.001$, and enjoyment, $t(450)=3.931, p<.001$. It would thus seem that these children find it easier to associate pleasure with reading than with writing and that they consider reading to be more important than writing. However, when it comes to their self-concepts as readers and writers-and bearing in mind that all of the items referred to the way in which they perceived their future success at learning and mastering written language-the results exhibited no significant differences, showing that the children considered that they would achieve equal degrees of success at reading and writing.

\section{Gender Effect}

In order to check the effect of the gender variable, we performed a comparative boy-girl analysis of the motivation scores of the reading. In regard to writing motivation scores they were very similar for the three dimensions considered (enjoyment, value, and 
self-concept) and gender differences were not statistically significant. When considering reading motivation only, the enjoyment of reading, $t(415,027)=-2.028, p=.04$, revealed a significant difference, with girls displaying greater motivation.

\section{Discussion}

One of our main aims was to characterize and analyze literacy motivation profiles of kindergarten children. As we can see, motivation for reading and writing is conceived as multidimensional by these children. We were able to identify three distinct and clearly differentiated dimensions in this regard: enjoyment, value and self-concept. It is interesting to note that these three aspects are narrowly associated with the three factors that Verhoven and Snow (2001) identified as underlying the formation of participative and engaged readers: understanding the uses, functions, and value of literacy (value of reading and writing); enthusiasm for learning as a result of positive experiences (enjoyment of reading and writing); and expectations of successful learning (self-concept as reader and writer).

It is also important to note that although the scores of the different dimensions were high and very similar, differences were found when comparing them. However, despite the fact that all three are important motives for reading and writing, the value/importance of reading and writing is the strongest motive. It is necessary to value reading and writing, to want to explore different literacy situations, and to use them in a meaningful way. In order to value writing and reading it is essential that one must have reasons to use and to feel the importance and necessity of written language. The place of literacy in the social structure of families and classrooms may influence the value that children attribute to reading and writing, and therefore their own literacy motivation. According to Nolen (2007) when observing people dealing with literacy situations, children may begin "to internalize adults' reasons for reading and writing as necessary for success in life or social relatedness" (pp. 222-223). These reasons are associated with the perceived functions of writing and reading related to the usefulness of literacy in everyday contexts.

Several authors in the field of emerging literacy have emphasized the importance of the appropriation of these literacy 
functions by children and the fact that children begin to identify and to use them early on, even when they are playing (McLane \& McNamee, 1990; Morrow, 1997; Newman \& Roskos, 1992). McLane and McNamee, and Goodman (1996) referred to the positive impact of understanding the functions of written language on the child's motivation to read.

Taking into consideration both theoretical frameworks on emergent literacy and on reading motivation, we can conclude that the importance of the value of reading and writing in the motivation profiles of children has some practical and pedagogical implications. These implications should be considered in the organization of classroom materials and situations for preschool children to explore and in the value attached to and stimulation of all family literacy activities that allow children to observe and participate in literacy situations in a meaningful and contextualized form. Participation and engagement in real literacy situations are fundamental in promoting the appropriation of literacy functions and to the value they attach to reading and writing (Mata, 2008a, 2008b). As Turner (1997) argued, students will not develop a sense of value for literacy activities unless the activities are authentic and attractive to them.

If we look at the three motivation domain scores (enjoyment, value, self-concept) it is instructive to note the relatively high levels of motivation in all of them. These high scores were not surprising considering the results of previous investigations on reading motivation and attitudes. Studies with students in the first years of elementary school have already identified motivations toward reading that are generally positive between the ages of 6 and 7 (Mazzoni et al., 1999; Monteiro \& Mata, 2001; Scher \& Baker, 1997). Research on reading attitudes in preschool children also indicates positive attitudes toward reading (Sperling \& Head, 2002). Similarly, Stipek and Ryan (1997) characterized motivation to learn and self-perception in preschool children, and Harter and Pike (1984) studied self-perception profiles of young children and verified a clear tendency toward high scores. Several explanations have been presented to justify this (Harter, 1990, 1999; Mata, 2006; Peixoto \& Mata, 1993; Wigfield, 2000): the developmental characteristics of preschool-age children, with limited capacity to understand their own performance and to compare it with that of others; the lack of formal experience in having the 
opportunity for social comparisons with other children or with previous performance; and the confusion that young children can experience between the desire to be competent and reality. Moreover, most preschool contacts and experiences with literacy are contextualized and take place in a positive environment, with significant others, without constraints and pressures (e.g., storybook reading, name writing). Gambrell and Gillis (2007) also referred to another important factor. The motivation scores of young children tend to be inflated because these children have not yet experienced notable failure or frustration due to their writing performance. All of these aspects can contribute to high reading and writing motivation profiles in the young children we have identified. According to Wigfield (2000), as children grow up, the realization that one is not as capable as others can decrease motivation. Teaching practices also may contribute to a decline in some children's motivation, when emphasizing social comparison and competition or mainly in the use of extrinsic rewards (Wigfield, 2000).

Wigfield et al. (2004) have asserted that children's beliefs in their own competence and intrinsic motivation were differentiated not only across subject areas but also in terms of degree. Children may be more strongly motivated in one particular area than in another. This idea is also highlighted by our results concerning the differentiation between reading and writing motivation profiles. The main characteristic observed in these kindergarten children is the evidence of a higher degree of motivation to read than to write. When comparing these differences with the appropriation of functions of reading and writing and with family literacy practices, we can identify some similar features. Mata (2006) has concluded that it is easier for 5-year-old children to nominate functions for reading than for writing. Parallel to this, parents prefer to develop functional reading practices at home in a more frequent and diversified way than they do with writing practices. Similar results were related by Lynch (2008) in a study with low-income families. Parents reported engaging with their children in fewer writing activities than reading activities. Helping children to write their names and the alphabet were the main focus of engagement with writing. Therefore, it seems that the scarcity of contacts with functional writing practices in the everyday contexts of preschool children makes the process of 
appropriation more difficult for writing aims and features, and children's motivation scores for writing tend to be lower than those for reading. As Paquette (2007) highlighted, to help children further understand the purpose of writing, classrooms should be "word rich" (e.g., labels, signs, environmental print). The more familiar children are with seeing and using written words, the more they will be empowered to use them in their daily writing. In addition, fostering authentic writing goals and contexts related to meaningful writing activities at home and in the classroom implies support for young writers' positive perceptions of themselves to develop confidence in their own writing abilities (Bruning \& Horn, 2000).

Finally, it is important to note that contrary to the results of a number of studies with older children (Baker \& Wigfield, 1999; McKenna, 2001; Monteiro \& Mata, 2001), among kindergarten children, boys and girls motivational profiles are not very differentiated. Only enjoyment of reading reveals a significant difference, with girls displaying greater motivation in this domain. It is interesting to note that in the value/importance and self-concept domains, where differences have been found between older boys and girls (Baker \& Wigfield; Monteiro \& Mata, 2001; Wigfield \& Guthrie, 1997), no differences were found in these kindergarten-age children. On the other hand, the question remains open as to whether the difference in terms of the enjoyment of reading that we found here is already an indication of the differences that Baker and Wigfield (1999) encountered among older children with regard to reading engagement or indeed those that McKenna et al. (1995) observed with regard to attitudes toward reading, even when controlling reading ability. The children who participated in our research were not yet attending school; therefore, reading and writing contacts were neither formal nor very structured. For that reason, perhaps gender expectations and stereotypes were not yet very evident or even powerful enough to have a significant impact on the children's motivation characteristics.

A more in-depth study is needed before more conclusive views can be taken; nevertheless, it does seem clear that at these ages, boys' and girls' motivation profiles do not display the differences found in school-age children. These differences are usually associated with social gender stereotypes and may emerge at a later stage of children's literacy development. 


\section{Conclusions}

The primary contribution of this investigation concerns the characterization of kindergarten children's motivation profiles for reading and for writing. Studies on affective components in the process of literacy acquisition for preschool children are few and there is a lack of suitable instruments to allow us to move toward a better understanding of their features. The identification of three distinct motivation dimensions, enjoyment, value, and selfconcept, confirm a precocious development of multidimensional reading and writing motivation profiles.

Considering these dimensions, kindergarten teachers can organize their actions and engage families with clear and sustained purposes. Even with young children it is important to consider the development of different facets of reading and writing motivations and to act in a purposeful way to promote them. These three dimensions are comprised in the four clusters of conditions considered by Bruning and Horn (2000) as most critical in developing writing motivation: nurturing beliefs about writing (competence as writer and writing value); engagement through authentic writing goals and contexts (real and challenging activities); creating a positive emotional environment; and providing supportive contexts for writing. Considering these elements, kindergarten teachers can act as real supporters of the development of motivated literacy learners. Motivated literacy learners were described by Gambrell and Gillis (2007) as those who choose to read and write, find pleasure in engaging in literacy activities, and consciously apply knowledge and strategies to more deeply comprehend and produce text. Therefore, they feel competent, they think that written language is valuable and useful for them, and they enjoy and feel pleasure when reading and writing.

As we have seen, kindergarten children are highly motivated to read and write, although writing motivation scores were not as high as those for reading. To prevent a considerable decline in writing motivation, children need opportunities to understand, value, and apply purposeful writing. Using writing in real-life situations can help children to discover and appropriate the various functions of writing (Mata, 2008a; Paquette, 2007).

In the ongoing research into reading and writing motivations in kindergarten children, there are some trajectories that seem to 
be of greater significance in reaching a deeper understanding. As we can see, research concerning reading motivation shows that, as children get older, their motivations for reading decrease, at least in some aspects (Baker \& Wigfield, 1999; Gambrell et al., 1996; Monteiro \& Mata, 2001; Wigfield \& Guthrie, 1997). Therefore, it is important to understand how precocious these declining patterns are and to study motivation characteristics in the transition to elementary school and during the early years of elementary school. On the other hand, with older students, the literature shows clear associations between reading motivation and reading performance and habits (Atkinson, 2006; Baker \& Wigfield, 1999; Guthrie \& Anderson, 1999; Morgan \& Fuchs, 2007; Morgan, Fuchs, Compton, Cordray, \& Fuchs, 2008; Unrau \& Schlackman, 2006). Thus, it is also important to know something about the motivation profiles of younger children and their emerging literacy. If we can obtain a more sustained and diverse knowledge of these aspects, we can conceptualize and organize developmental reading and writing strategies to promote students' engagement with literacy more effectively.

\section{References}

Alves Martins, M. (1994). Conceptualizações infantis sobre linguagem escrita e aprendizagem da leitura [Children's perceptions toward written language and learning to read]. Discursos. Estudos de Lingua e Cultura Portuguesa, 8, $53-70$.

Atkinson, C. (2006). Key stage 3 pupils' views about reading. Educational Psychology in Practice, 22, 321-336.

Baker, L. (1999). Opportunities at home and in the community that foster reading engagement. In J. Guthrie \& D. Alvermann (Eds.), Engaged reading: Processes, practices, and policy implications (pp. 105-133). New York, NY: Teachers College Press.

Baker, L., Afflerbach, P., \& Reinking, D. (1996). Developing engaged readers in school and home communities: An overview. In L. Baker, P. Afflerbach, \& D. Reinking (Eds.), Developing engaged readers in school and home communities (pp. xiii-xxvii). Mahwah, NJ: Lawrence Erlbaum.

Baker, L., Dreher, M., \& Guthrie, J. (2000). Why teachers should promote reading engagement. In L. Baker, M. Dreher, \& J. Guthrie (Eds), Engaging young readers-Promoting achievement and motivation (pp. 1-16). New York, NY: Guilford.

Baker, L., \& Wigfield, A. (1999). Dimensions of children's motivation for reading and their relations to reading activity and reading achievement. Reading Research Quarterly, 34, 452-477. 
Bruning, R., \& Horn, C. (2000). Developing motivation to write. Educational Psychologist, 35, 25-37.

Clay, M. (1999). What did I write? Beginning writing behavior (16th ed.). Portsmouth, NH: Heinemann.

Clay, M. (2000). Concepts about print. What have children learned about the way we print language? Portsmouth, NH: Heinemann.

Codling, M. R., \& Gambrell, L. (1997). The motivation to write profile: An assessment tool for elementary teachers. Athens, GA: National Reading Research Center.

Eccles, J., O'Neill, S., \& Wigfield, A. (2005). Ability self-perception and subjective task values in adolescents and children. In K. Moore \& L. Lipman (Eds.), What do children need to flourish? Conceptualizing and measuring indicators of positive development (pp. 237-249). New York, NY: Springer.

Eccles, J., \& Wigfield, A. (2002). Motivational beliefs, values and goals. Annual Review Psychology, 53, 109-132.

Ferreiro, E. (1988). Literacy development: A psychogenetic perspective. In D. Olson, N. Torrance, \& A. Hildyard (Eds.), Literacy, language and learning. The nature and consequences of reading and writing (pp. 217-228). New York, NY: Cambridge University Press.

Gambrell, L., \& Gillis, V. (2007). Assessing children's motivation for reading and writing. In J. Paratore \& R. McCormack (Eds.), Classroom literacy assessment-Making sense of what students know and do (pp. 50-64). New York, NY: Guilford.

Gambrell, L., Palmer, B., Codling, R., \& Mazzoni, S. (1996). Assessing motivation to read. The Reading Teacher, 49, 518-533.

Garcia, J., \& Caso, A. (2004). Effects of a motivational intervention for improving the writing of children with learning disabilities. Learning Disability Quarterly, 27, 141-159.

Goodman, Y. (1989). Children coming to know literacy. In W. Teale \& E. Sulzby (Eds.), Emergent literacy-Writing and reading (2nd ed., pp. 1-14). Norwood, NJ: Ablex Publishing Corporation.

Goodman, Y. (1996). Beginning reading development: Strategies and principles. In S. Wilde (Ed.), Notes from a kidwatcher. Selected writings of Yetta M. Goodman (pp. 148-161). Portsmouth, NH: Heinemann.

Guthrie, J., \& Anderson, E. (1999). Engagement in reading: Processes of motivated, strategic, knowledgeable, social readers. In J. T. Guthrie \& D. Alvermann (Eds.), Engaged reading: Processes, practices, and policy implications (pp. 17-45). New York, NY: Teachers College Press.

Guthrie, J., \& Knowles, K. (2001). Promoting reading motivation. In L. Verhoven \& C. Snow (Eds.), Literacy and motivation. Reading engagement in individuals and groups (pp. 159-176). Mahwah, NJ: Lawrence Erlbaum.

Guthrie, J., McRae, A., Coddington, C., Klauda, S., Wigfield, A., \& Barbosa, P. (2009). Impacts of comprehensive reading instruction on diverse outcomes of low- and high-achieving readers. Journal of Learning Disabilities, 42, 195-214.

Guthrie, J., McRae, A., \& Klauda, S. (2007). Contributions of concept-oriented reading instruction to knowledge about interventions for motivations in reading. Educational Psychologist, 42, 237-250. 
Guthrie, J., \& Wigfield, A. (1997). Reading engagement: A rationale for theory and teaching. In J. Guthrie \& A. Wigfield (Eds), Reading engagement. Motivating readers through integrated instruction (pp. 1-12). Newark, DE: International Reading Association.

Guthrie, J., Wigfield, A., Barbosa, P., Perencevich, K., Taboada, A., Davis, M., ..., Tonks, S. (2004). Increasing reading comprehension and engagement through concept-oriented reading instruction. Journal of Educational Psychology, 96, 403-423.

Harter, S. (1990). Causes, correlates and functional role of global self-worth: A life-span perspective. In J. Kolligian \& R. Sternberg (Eds.), Perceptions of competence and incompetence across the life-span (pp. 67-97). New Haven, CT: Yale University Press.

Harter, S. (1999). The construction of the self: A developmental perspective. New York, NY: Guilford.

Harter, S., \& Pike, R. (1984). The pictorial perceived competence scale and acceptance for young children. Child Development, 55, 1969-1982.

Harter, S., Whitesell, N. R., \& Kowalksi, P. (1992). Individual differences in the effects of educational transitions on young adolescents' perceptions of competence and motivational orientation. American Educational Research Journal, 29, 777-808.

Lepper, M., Corpus, J., \& Iyengar, S. (2005). Intrinsic and extrinsic motivational orientations in the classroom: Age differences and academic correlates. Journal of Educational Psychology, 97, 184-196.

Lynch, J. (2008). Engagement with print: Low-income families and Head Start children. Journal of Early Childhood Literacy, 8, 151-175.

Mata, L. (2006). Literacia familiar [Family literacy]. Porto, Portugal: Porto Editora.

Mata, L. (2008a). A descoberta da escrita [Written language discovery]. Lisbon, Portugal: Editorial do Ministério da Educação.

Mata, L. (2008b). Avaliação dos conhecimentos sobre a funcionalidade da linguagem escrita [Assessment of knowledge in written language functionality]. In A. P. Machado, C. Machado, L. S. Almeida, M. Gonçalves, S. Martins, \& Vera Ramalho (Eds.), Actas da XIII Conferência Internacional Avaliação Psicológica: Formas e Contextos. Braga, Portugal: Psiquilíbrios.

Mata, L., Monteiro, V., \& Peixoto, F. (2009). Motivação para a leitura ao longo da escolaridade [Reading motivation throughout school]. Análise Psicológica, 27, 563-572.

Mata, L., \& Pacheco, P. (2009). Caracterização das práticas de literacia familiar [Characterization of family literacy practices]. In B. Silva, L. Almeida, A. Lozano, \& M. Uzquiano (Eds.), Actas do X Congresso Galaico-Português de Psicopedagogia (pp. 1741-1753). Braga, Portugal: Centro de Investigação em Educação, Universidade do Minho.

Mazzoni, S., Gambrell, L., \& Korkeamaki, R. (1999). A cross-cultural perspective of early literacy motivation. Journal of Reading Psychology, 20, 237-253.

McKenna, M. (2001). Development of reading attitudes. In L. Verhoeven \& C. Snow (Eds.), Literacy and motivation. Reading engagement in individuals and groups (pp. 135-158). Mahwah, NJ: Lawrence Erlbaum. 
McKenna, M., Kear, D., \& Ellsworth, R. (1995). Children's attitudes toward reading: A national survey. Reading Research Quarterly, 30, 934-955.

McLane, J., \& McNamee, G. (1990). The developing child series. Early literacy. Cambridge, MA: Harvard University Press.

Meece, J., \& Miller, S. (1999). Changes in elementary school children's achievement goals for reading and writing: Results of a longitudinal and intervention study. Scientific Studies of Reading, 3, 207-229.

Monteiro, V., \& Mata, L. (2001). Motivação para a leitura em crianças do $1^{\circ}, 2^{\circ}$, $3^{\circ}$ e $4^{\circ}$ ano de escolaridade [Reading motivation in students from 1st, 2nd, 3rd and 4th grades]. Infância e Educação. Investigação e Práticas, 3, 49-68.

Morgan, P., \& Fuchs, D. (2007). Is there a bidirectional relationship between children's reading skills and reading motivation? Exceptional Children, 73, 165-183.

Morgan, P., Fuchs, D., Compton, D., Cordray, D., \& Fuchs, L. (2008). Does early reading failure decrease children's reading motivation? Journal of Learning Disabilities, 41, 387-404.

Morrow, L. (1997). Literacy development in the early years-Helping children read and write. Boston, MA: Allyn \& Bacon.

Neuman, S., \& Roskos, K. (1992). Literacy objects as cultural tools: Effects on children's literacy behaviours in play. Reading Research Quarterly, 27, 203-225.

Nolen, S. (2007). Young children's motivation to read and write: Development in social contexts. Cognition and Instruction, 25, 219-270.

Pajares, F., \& Cheong, Y. (1997). Achievement goal orientations in writing: A developmental perspective. International Journal of Education Research, 39, 437-455.

Pajares, F., Miller, D., \& Johnson, M. (1999). Gender differences in writing selfbeliefs of elementary school students. Journal of Educational Psychology, 91, 50-61.

Pajares, F., \& Valiante, G. (1997). Influence of self-efficacy on elementary students' writing. The Journal of Educational Research, 90, 353-360.

Pajares, F., \& Valiante, G. (2001). Gender differences in writing motivation and achievement of middle school students: A function of gender orientation. Contemporary Educational Psychology, 26, 366-381.

Pajares, F., Valiante, G., \& Cheong, Y. (2007). Gender, writing motivation and writing competence: A developmental perspective. In S. Hidi \& P. Boscolo (Eds.), Writing and motivation (pp. 141-160). Oxford, England: Elsevier.

Pajares, F., \& Cheong, Y. F. (2003). Achievement goal orientations in writing: A developmental perspective. International Journal of Educational Research, 39, 437-455.

Pajares, F., \& Valiante, G. (1999). Grade level and gender differences in the writing selfbeliefs of middle school students. Contemporary Educational Psychology, 24, 390-405.

Paquette, K. (2007). Encouraging primary students' writing through children's literature. Early Childhood Education Journal, 35, 155-165.

Peixoto, F., \& Mata, L. (1993). Efeitos da idade, sexo e nível sociocultural no autoconceito [Effects of age, gender and socio-cultural level on self-concept]. Análise Psicológica, 11, 401-413. 
Pitcher, S., Albright, L., DeLaney, C., Walker, N., Seunarinesingh, K., Mogge, S., ... Dunston, P. (2007). Assessing adolescents' motivation to read. Journal of Adolescent E Adult Literacy, 50, 378-396.

Saracho, O., \& Dayton, C. (1991). Age-related changes in reading attitudes of young children: A cross-cultural study. Journal of Research in Reading, 14, 33-45.

Scher, D., \& Baker, L. (1997). Children's conceptions and motivations regarding reading and their relations to parental ideas and home experiences. In Serpell, R., Sonnenschein, S., \& Baker, L. (Eds), In patters of Emerging competence and sociocultural context in the early approprioation of literacy. Symposium conducted at the meeting for the Society for Research in Child Development, Washington, DC.

Schutte, N., \& Malouff, J. (2007). Dimensions of reading motivation: Development of an adult reading motivation scale. Reading Psychology, 28, 469-489.

Sonnenschein, S., \& Munsterman, K. (2002). The influence of home-based reading interactions on 5-year-olds' reading motivations and early literacy development. Early Childhood Research Quarterly, 17, 318-337.

Sperling, R., \& Head, D. (2002). Reading attitudes and literacy skills in prekindergarten and kindergarten children. Early Childhood Education Journal, 29, 233-236.

Stipek, D., \& Ryan, R. (1997). Economically disadvantaged preschoolers: Ready to learn but further to go. Developmental Psychology, 33, 711-723.

Sulzby, E. (1989). Writing and reading: Signs of oral and written language organization in the young child. In W. Teale \& E. Sulzby (Eds), Emergent literacy-Writing and reading (2nd ed., pp. 50-89). Norwood, NY: Ablex.

Turner, J. (1997). Starting right: Strategies for engaging young literacy learners. In J. Guthrie \& A. Wigfield (Eds.), Reading engagement. Motivating readers through integrated instruction (pp. 183-204). Newark, DE: International Reading Association.

Unrau, N., \& Schlackman, J. (2006). Motivation and its relationship with reading achievement in an urban middle school. The Journal of Educational Research, 100, 81-101.

Valeski, T., \& Stipek, D. (2001). Young children's feelings about school. Child Development, 72, 1198-1213.

Verhoven, L., \& Snow, C. (2001). Literacy and motivation: Bridging cognitive and sociocultural viewpoints. In L. Verhoven \& C. Snow (Eds.), Literacy and motivation. Reading engagement in individuals and groups (pp. 1-20). Mahwah, NJ: Lawrence Erlbaum.

Wigfield, A. (1997). Reading motivation: A domain-specific approach to motivation. Educational Psychologist, 32, 59-68.

Wigfield, A. (2000). Facilitating children's reading motivation. In L. Baker, M. Dreher, \& J. Guthrie (Eds.), Engaging young readers_Promoting achievement and motivation (pp. 140-158). New York, NY: Guilford.

Wigfield, A., \& Guthrie, J. (1997). Relations of children's motivation for reading to the amount and breadth of their reading. Journal of Educational Psychology, 89, 420-432. 
Wigfield, A., Guthrie, J., \& McGough, K. (1996). A questionnaire measure of children's motivations for reading. (Instructional Resource no 22). Athens, GA: National Reading Research Centre.

Wigfield, A., Guthrie, J., Tonks, S., \& Perencevich, K. (2004). Children's motivation for reading: Domain specificity and instructional influences. The Journal of Educational Research, 97, 299-309.

Wilson, K., \& Trainin, G. (2007). First-grade students' motivation and achievement for reading, writing, and spelling. Reading Psychology, 28, 257-282.

\section{Appendix}

Total of the 36 Items Created to Be Tested for the Reading and Writing Motivation Scale (RWMS)

\begin{tabular}{|c|c|c|c|}
\hline & Reading Items & & Writing Items \\
\hline ER1 & $\begin{array}{l}\text { Likes when gets books for } \\
\text { presents }^{\mathrm{a}}\end{array}$ & EW19 & $\begin{array}{l}\text { Likes when gets papers, } \\
\text { pencils, and pens for } \\
\text { presents }\end{array}$ \\
\hline VR2 & $\begin{array}{l}\text { It is necessary to know how } \\
\text { to read to do well at } \\
\text { school }^{\mathrm{a}}\end{array}$ & VW20 & $\begin{array}{l}\text { It is necessary to know how } \\
\text { to write to do well at } \\
\text { school }\end{array}$ \\
\hline SCR3 & $\begin{array}{l}\text { Is going to be able to read } \\
\text { many things next year }\end{array}$ & SCW21 & $\begin{array}{l}\text { Is going to be able to write } \\
\text { a lot of things next year }\end{array}$ \\
\hline ER 4 & $\begin{array}{l}\text { Enjoys when parents read } \\
\text { stories }^{\text {a }}\end{array}$ & EW22 & $\begin{array}{l}\text { Enjoys when parents write } \\
\text { with him or her }\end{array}$ \\
\hline VR5 & $\begin{array}{l}\text { It is important to know how } \\
\text { to read }\end{array}$ & VW23 & $\begin{array}{l}\text { It is important to know how } \\
\text { to write }\end{array}$ \\
\hline SCR6 & $\begin{array}{l}\text { Reading is going to be } \\
\text { difficult/easy }\end{array}$ & SCW24 & $\begin{array}{l}\text { Writing is going to be } \\
\text { difficult/easy }\end{array}$ \\
\hline ER7 & Enjoys looking at books ${ }^{\mathrm{a}}$ & EW25 & Enjoys writing \\
\hline VR8 & $\begin{array}{l}\text { People learn things when } \\
\text { they read }\end{array}$ & VW26 & $\begin{array}{l}\text { People learn things when } \\
\text { they write }\end{array}$ \\
\hline SCR9 & $\begin{array}{l}\text { Is going to learn to read } \\
\text { well }^{\mathrm{a}}\end{array}$ & SCW27 & $\begin{array}{l}\text { Is going to learn to write } \\
\text { well }\end{array}$ \\
\hline ER10 & $\begin{array}{l}\text { Reading is a good way to } \\
\text { spend time }\end{array}$ & EW28 & $\begin{array}{l}\text { Writing is a good way to } \\
\text { spend time }\end{array}$ \\
\hline VR11 & $\begin{array}{l}\text { People can discover new } \\
\text { things when they read }\end{array}$ & VW29 & $\begin{array}{l}\text { People can discover new } \\
\text { things when they write }\end{array}$ \\
\hline SCR12 & $\begin{array}{l}\text { Is going to manage to read } \\
\text { schoolwork well next } \\
\text { year }\end{array}$ & SCW30 & $\begin{array}{l}\text { Is going to manage to write } \\
\text { schoolwork well next } \\
\text { year }\end{array}$ \\
\hline ER13 & Reading is boring/fun ${ }^{\mathrm{a}}$ & EW31 & Writing is boring/fun \\
\hline VR14 & $\begin{array}{l}\text { It is necessary to read } \\
\text { things everyday }\end{array}$ & VW32 & $\begin{array}{l}\text { It is necessary to write } \\
\text { things everyday }\end{array}$ \\
\hline
\end{tabular}


Reading Items
Writing Items

\begin{tabular}{|c|c|c|c|}
\hline SCR15 & $\begin{array}{l}\text { Is going to be able to read } \\
\text { stories well next year }\end{array}$ & SCW33 & $\begin{array}{l}\text { Is going to be able to write } \\
\text { stories well next year }\end{array}$ \\
\hline ER16 & Reading is good & EW34 & Writing is good \\
\hline SCR17 & $\begin{array}{l}\text { Already knows how to read } \\
\text { lots of things }\end{array}$ & SCW35 & $\begin{array}{l}\text { Already knows how to write } \\
\text { lots of things }\end{array}$ \\
\hline ER 18 & $\begin{array}{l}\text { Likes to look at books for } \\
\text { long periods. }\end{array}$ & EW36 & $\begin{array}{l}\text { Likes writing for long } \\
\text { periods. }\end{array}$ \\
\hline
\end{tabular}

Note. $\mathrm{VR}=$ value of reading; $\mathrm{VW}=$ value of writing; $\mathrm{ER}=$ Enjoyment in reading; $\mathrm{EW}=$ Enjoyment in writing; SCR = self-concept as a reader; SCW = self-concept as a writer.

atems similar to or inspired by those from the Motivation for Reading Scale (Scher \& Baker, 1997). 